\title{
Structural development of Maglevandsfald: a key to understanding the glaciotectonic architecture of Møns Klint, SE Denmark
}

\author{
Stig A. Schack Pedersen and Peter Gravesen
}

The Møns Klint Glaciotectonic Complex (Fig. 1) exposed in the $\mathrm{N}-\mathrm{S}$-trending chalk cliff on the east coast of the island of Møn in south-east Denmark is one of the most famous glaciotectonic geosites in the world. People of all nationalities are attracted to the site, which has more than 300000 visitors per year. Many of them may not realise the uniqueness of the glaciotectonic framework, and are probably more fascinated by the spectacular view of the white cliff and chalk peaks separated by the deep green gorges. However, without the glaciotectonic deformation the cliffs would never have formed. Instead the Cretaceous chalk would still have been resting horizontally below the seabed, covered by glaciofluvial sand, glaciolacustrine clay and clayey till.

In the summer 2007, a new natural science exhibition centre, GeoCenter Møns Klint, was opened. The exhibition focuses on the geology of Denmark with special reference to the chalk cliffs of Møns Klint. Prior to the decision to build the centre, the Geological Survey of Denmark and Greenland was asked to provide an evaluation of the landslide risk for the site, because landslides regularly occur along the cliff section (Pedersen 2003). A detailed structural analysis was consequently carried out at the planned site of the centre just above the Maglevandsfald gorge (Fig. 1). During this investigation it became obvious that understanding the glaciotectonic framework was a prerequisite for the geological risk analysis. Thus the structural details at Maglevandsfald became a key point for the glaciotectonic model of Møns Klint which we present in this paper.

\section{Geological setting of Møns Klint}

The Cretaceous chalk represents the oldest bedrock affected by glaciotectonic thrusting in Denmark. The chalk consists of a fine-grained matrix of coccoliths and remains from invertebrates (Surlyk \& Håkansson 1999). The chalk at Møn is correlated with the upper part of the Tor Formation in the North Sea and the Danish Basin (Surlyk et al. 2003).

An erosional unconformity on top of the chalk represents a hiatus of about 60 million years. Due to erosion, the unconformity is found at gradually lower and lower levels towards the southern part of the cliff, which indicates that the pre-Quaternary relief probably contributed to the formation of glaciotectonics in the area. In some parts of Møn the pre-Quaternary unconformity is overlain by a Saalian till, marine Eemian clay and three Weichselian tills intercalated by glaciolacustrine and glaciofluvial deposits (Houmark-Nielsen 1994). However, at Møns Klint an old Weichselian till is the oldest Quaternary deposit recognised at present (Pedersen \& Gravesen 2006). This till is a grey and reddish sandy till that grades up into a gravelly, stone-rich top surface indicating terrestrial conditions. We tentatively correlate this unit with the Ristinge Klint Till (HoumarkNielsen 1987, 1994), which was deposited by a Baltic ice stream in the early part of the Weichselian (c. 60000 years BP) from a source area in the Baltic Sea. When the Baltic Ice Stream melted back the depression became occupied by a huge lake, in which dark glaciolacustrine mud rich in dropstones was deposited (Houmark-Nielsen 1994; Houmark-Nielsen \& Kjær 2003).

Fig. 1. Aerial photograph of Møns Klint. The highest cliff in the centre is Dronningestolen. To the left the Maglevandsfald gorge leads from the location of GeoCenter Møns Klint down to the beach. At the left side of Dronningestolen a wedge-shaped structure is seen (red arrow), which was formed in the first deformation phase of the glaciotectonic complex. The thrust structures to the right of Dronningestolen were thrust to the SW during the last deformation phase. The location of Møns Klint is shown on the inset map of Denmark.

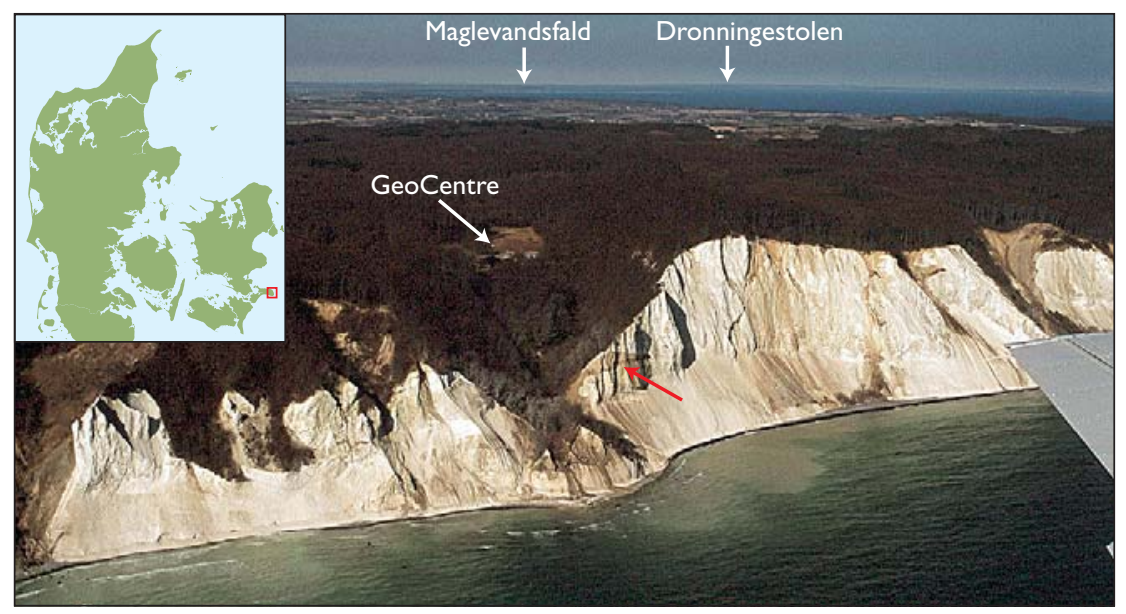




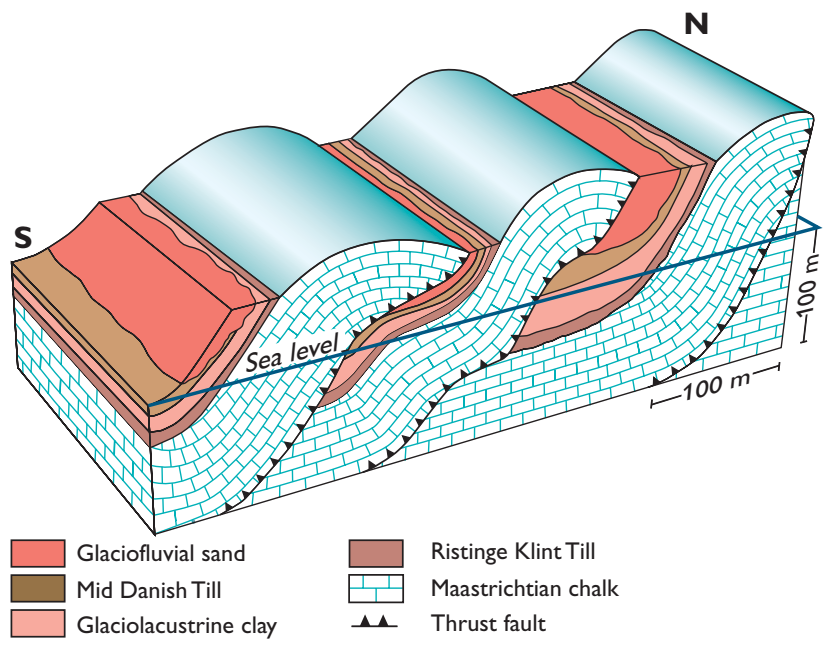

Fig. 2. Stratigraphical and structural framework of the southern imbricate fan at Møns Klint. The thickness of the lithological units is variable, and especially the glaciofluvial sand above the Mid Danish Till increases in thickness, where the sand was deposited in piggyback basins during the thrust-fault deformation. From Pedersen \& Gravesen (2006).

The unit is informally called the elephant clay due to its characteristic erosion features. At the Late Weichselian glacial maximum the Swedish Ice advanced over the eastern part of the Danish Basin onto the Main Stationary Line depositing the Mid Danish Till on Møn (Fig. 2; Houmark-Nielsen 1987; Pedersen \& Gravesen 2006).

At about 18000 years BP the Young Baltic Ice Stream reached Møn (Houmark-Nielsen \& Kjær 2003). The pressure from the ice was directed away from the central axis of the ice stream towards both north and south, where it thrust up the chalk sheets at Møns Klint. The glaciotectonic structures at Møns Klint can be divided into three architectural elements. In the southern part the thrust sheets form an imbricate fan with thrust faults striking $\mathrm{E}-\mathrm{W}$, in the central part the structures form an antiformal stack, and farthest to the north the thrust sheets dip gently to the south in the foreland regime of the thrust deformation (Fig. 3; Pedersen 2000). Towards the end of the Weichselian the Scandinavian ice sheet melted back. However, a readvance from southern Sweden reached Møn from eastnorth-east at a time between 17000 and 15000 years BP, which was responsible for superimposed deformation of the glaciotectonic complex (Pedersen 2000).

\section{Photogrammetric mapping and a borehole investigation}

A 3-D terrain model of the area was developed for the risk evaluation. The data for the model were provided by a photogrammetric survey and a digital model was constructed, in which the trace of the glacial deposits, interbedded between the unconformity on top of the chalk and the base of an over- thrust chalk sheet, was positioned (Fig. 4). In addition, a borehole was drilled to investigate whether karst cavities or an unforeseen thrust-fault zone with dip towards the cliff and beach were present. If a fault zone exists below the location it could be a candidate for a landslip similar to the one that destroyed the Store Taler chalk peak in January 2007 (Fig. 5). The borehole was placed on top of the cliff $100 \mathrm{~m}$ above sea level close to the old Hotel Store Klint (Fig. 6). The uppermost $16.3 \mathrm{~m}$ consist of glacial sediments resting upon the chalk unconformally. The oldest unit in the glacial succession is a $1 \mathrm{~m}$ thick till that is correlated with the Ristinge Klint Till. This formation is overlain by $2.3 \mathrm{~m}$ glaciolacustrine mud, which grades into the nearly $2 \mathrm{~m}$ thick Mid Danish Till. A $7.7 \mathrm{~m}$ thick unit of glaciofluvial sand and gravel overlies the Mid Danish Till; the upper part of the glacial succession is a 3.5 m thick, sandy till that was deposited by the Young Baltic Ice. Below the unconformity the drilling penetrated $48 \mathrm{~m}$ of Cretaceous chalk, after which the drilling was

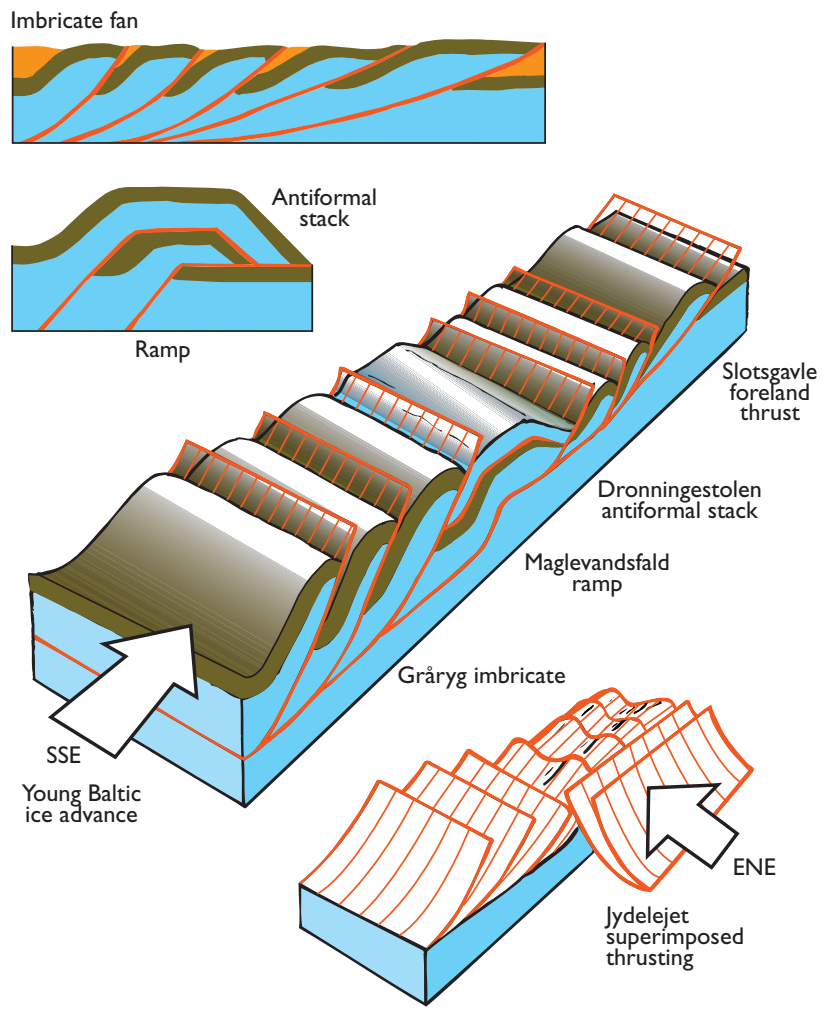

Fig. 3. Principal structural framework of the Møns Klint Glaciotectonic Complex. Blue: chalk; brown and orange: Quaternary deposits. Red lines outline the thrust faults. To the south the E-W-trending ridges represent an imbricate fan, and in the central part an antiformal stack is responsible for the formation of Dronningestolen. Two principal sketches of the structures are shown in the top left corner. In the distal part of the complex to the north a gently dipping imbricate fan was formed in the nearforeland regime. The structures from the distal regime to Maglevandsfald were strongly affected by superimposed deformation caused by a readvance of ice from Skåne. After Pedersen (2000). 


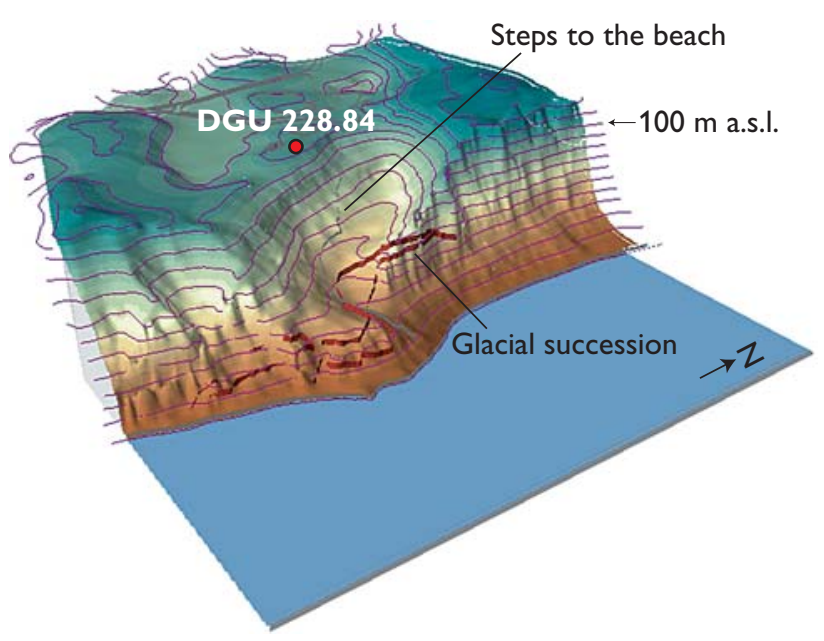

Fig. 4. 3-D model of the Maglevandsfald gorge. The position of the exploratory borehole DGU 228.84 is indicated with a dot, located between the exhibition centre and the old hotel. The upper and lower boundaries of the glacial succession are shown with a brown line. Contour interval $10 \mathrm{~m}$.

unfortunately stopped for logistic reasons. It would have been perfect if the borehole had reached the level of the lower thrust fault and the underlying glacial succession. However, the data demonstrate that neither a karst cavity nor an eastward dipping thrust-fault zone was present.

\section{Thrust-fault tectonics and superimposed deformation}

The structures in the Møns Klint Glaciotectonic Complex are directly comparable to structures in thin-skinned thrustfault belts formed by gravity spreading (Pedersen 2005). The geomorphological expression of a mountain range is clearly seen in the parallel-ridged landscape of Høje Møn (the eastern, hilly part of Møn). For detailed structural analysis five cross-sections were constructed across the Maglevandsfald (Figs 6,7 ). The data for the cross-sections were taken from the photogrammetric survey combined with a structural investigation of the cliff section immediately south of Maglevandsfald. In the cross-sections two horizons of glacial successions are shown (Fig. 7). The lower glacial horizon rests on the unconformity on top of the chalk. The top of the glacial deposits is bordered by a thrust fault, where the base of the chalk sheet can be classified as a hanging-wall flat related to the earliest glaciotectonic deformation. Farther to the south this flat can be followed into a hanging-wall ramp, which dips into the subsurface below the beach. This ramp strikes $\mathrm{E}-\mathrm{W}$, indicating that it is part of the antiformal stack structure (Fig. 3). As the décollement zone must be situated at the base of the chalk unit, which in Fig. 7 can be seen to be about $60 \mathrm{~m}$ thick, the depth to this zone must be of similar

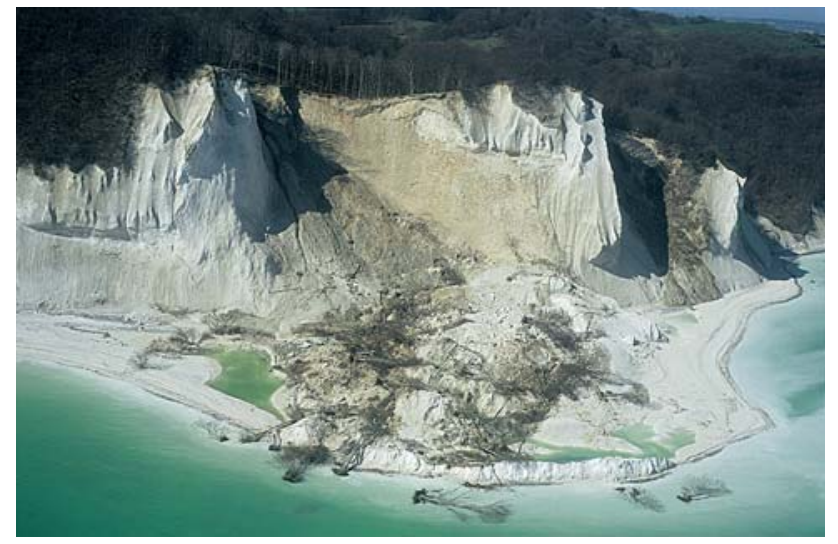

Fig. 5. The landslide at Store Taler took place at the end of January 2007. A volume of more than $100000 \mathrm{~m}^{3}$ was displaced along an inherited thrust-fault surface formed during the last phase of deformation at Møns Klint. Store Taler is located in the northern part of Møns Klint.

magnitude, probably about $75 \mathrm{~m}$ below sea level. Therefore the chalk below the lower glacial unit is also interpreted as a thrust sheet lifted up from the décollement zone.

The lower glacial unit is folded in a SW-verging overturned structure, which has been deformed by the second glaciotectonic event. The structure is partly hidden by soil and vegetation in the Maglevandsfald gorge, but the upper limb of the structure is exposed at the cliff edge of Maglevandsnakken (Fig. 7), where the unit continues into the wedge-shaped feature in the southern part of the Dronningestolen cliff section (Fig. 1). The wedge-shaped feature was formed during the foreland-dipping thrusting of the antiformal stack (compare with Fig. 3). The thrust-fault flat

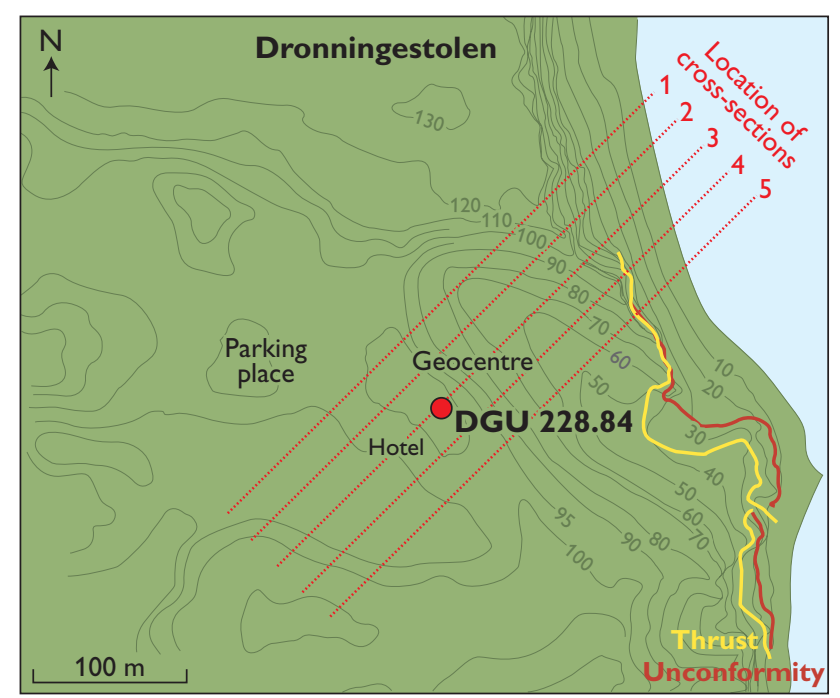

Fig. 6. The Maglevandsfald area with location of the exploratory borehole mentioned in the text and the cross-sections applied in the structural analysis. 

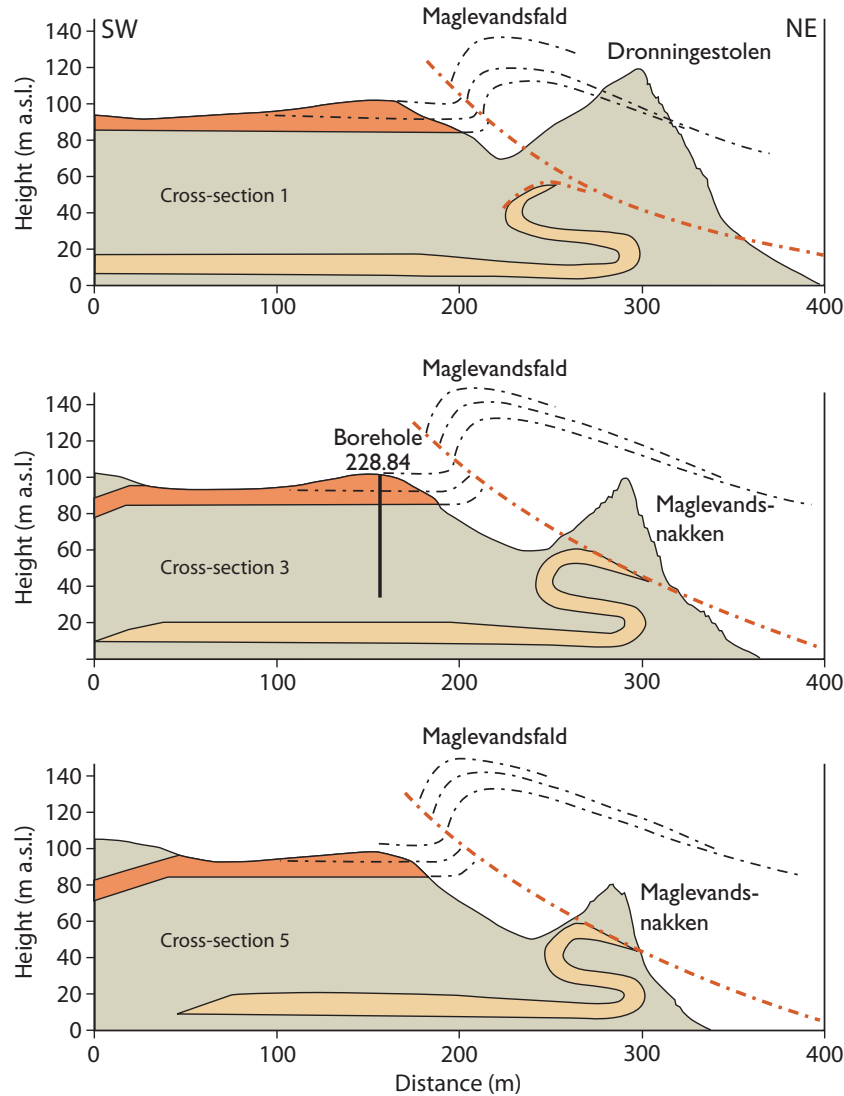

Glacial succession on top of upper thrust sheet $\quad$. Thrust fault Glacial succession at the base of the cliff

Fig. 7. Three of the cross-sections across the Maglevandsfald gorge (for location see Fig. 6). The cross-sections were constructed perpendicular to the fold axis of the last deformation, which created a recumbent anticline and syncline pair below a thrust fault with a displacement of $20 \mathrm{~m}$. The folding is outlined in the glacial units below the thrust-fault flat of the first deformation, which is responsible for the wedge-shaped feature in the top of the fold. The strike of the first deformation thrust is oblique to the second phase fold axis, and therefore the position of the wedge changes from cross-section to cross-section. In cross-section 5 the tip of the thrust wedge touches the cliff edge, which corresponds to the exposure of the wedge seen in Fig. 1 immediately to the right of Maglevandsfald.

above the glacial unit is folded in the Maglevandsfald gorge structure with a fold axis trending NW-SE, which demonstrates the superimposed deformation. A similar wedge-shaped structure is present just below the edge of the Dronningestolen cliff, which may indicate that a thrust sheet existed even higher in the antiformal stack before the Young Baltic Ice truncated the structure during the advance towards NNW.

\section{Final remarks}

Møns Klint is one of the most famous glaciotectonic localities in the world. The structures in the Møns Klint Glaciotectonic Complex are comparable to structures in thinskinned thrust-fault belts formed by gravity spreading. The glaciotectonic complex is responsible for the parallel-ridge landscape known as Høje Møn, where Aborre Bjerg (143 m) represents the highest hill in eastern Denmark. A combination of an imbricate fan and an antiformal stack is responsible for the impressive tectonic complex. Its main architecture was formed during the Young Baltic Ice Stream advance dated to about 18000 years BP, but a readvance of ice from southern Sweden from 17000 to 15000 years BP is responsible for the superimposed deformation of the complex.

The most impressive unit forming the thrust sheets is the Maastrichtian chalk. The chalk is part of the huge carbonate platform that spread over northern Europe during the late Cretaceous. The top surface of the chalk, the pre-Quaternary unconformity, was originally situated more than $20 \mathrm{~m}$ below sea level, and the décollement zone for the thrusting is probably located about $80-100 \mathrm{~m}$ below sea level in a marl-rich variety of the chalk.

\section{References}

Houmark-Nielsen, M. 1987: Pleistocene stratigraphy and glacial history of the central part of Denmark. Bulletin of the Geological Society of Denmark 36, $1-189$.

Houmark-Nielsen, M. 1994: Late Pleistocene stratigraphy, glacial chronology and Middle Weichselian environmental history from Klintholm, Møn, Denmark. Bulletin of the Geological Society of Denmark 41, 181-202.

Houmark-Nielsen, M. \& Kjær, K. 2003: Southwest Scandinavia, 40-15 kyr BP: palaeography and environmental change. Journal of Quaternary Science 18, 769-786.

Pedersen, S.A.S. 2000: Superimposed deformation in glaciotectonics. Bulletin of the Geological Society of Denmark 46, 125-144.

Pedersen, S.A.S. 2003: Vurdering af skredrisiko for området oven for Maglevandsfaldet på Møns Klint. Strukturel undersøgelse af de glacialtektoniske forhold i klintområdet ved Hotel Storeklint, Møns Klint, Møn. Danmarks og Grønlands Geologiske Undersøgelse Rapport 2003/50, 31 pp.

Pedersen, S.A.S. 2005: Structural analysis of the Rubjerg Knude Glaciotectonic Complex, Vendsyssel, northern Denmark. Geological Survey of Denmark and Greenland Bulletin 8, 192 pp.

Pedersen, S.A.S. \& Gravesen, P. 2006: Geological map of Denmark, 1:50 000, Møn. Copenhagen: Geological Survey of Denmark and Greenland.

Surlyk, F. \& Håkansson, E. 1999: Maastrichtian and Danian strata in the southeastern part of the Danish Basin. In: Pedersen, G.K. \& Clemmensen, L.B. (eds): IAS Field trip guidebook. Contribution to Geology, 29-58. Copenhagen: Geological Museum, University of Copenhagen.

Surlyk, F., Dons, T., Clausen, C.K. \& Higham, J. 2003: Upper Cretaceous. In: Evans, D. et al. (eds): The millennium atlas: Petroleum geology of the central and northern North Sea, 213-233. London: The Geological Society of London.

\section{Authors' address}

Geological Survey of Denmark and Greenland, Øster Voldgade 10, DK-1350 Copenhagen K, Denmark. E-mail: sasp@geus.dk 